February 2022

\title{
Editorial: The inaugural issue of Journal of Global Hospitality and Tourism
}

\author{
Faizan Ali \\ University of South Florida, faizanali@usf.edu \\ Seden Dogan \\ Ondokuz Mayıs University, seden.dogan@omu.edu.tr
}

Follow this and additional works at: https://digitalcommons.usf.edu/jght

Part of the Hospitality Administration and Management Commons, and the Other Business Commons This Editorial is brought to you for free and open access by the M3 Center at the University of South Florida Sarasota-Manatee at Digital Commons @ University of South Florida. It has been accepted for inclusion in Journal of Global Hospitality and Tourism by an authorized editor of Digital Commons @ University of South Florida. For more information, please contact digitalcommons@usf.edu.

\section{Recommended Citation}

Ali, F., \& Dogan, S. (2022). Editorial: The inaugural issue of Journal of Global Hospitality and Tourism. Journal of Global Hospitality and Tourism, 1(1), 90-92. https://www.doi.org/10.5038/2771-5957.1.1.1007 


\title{
Editorial
}

\section{The Inaugural Issue of Journal of Global Hospitality and Tourism}

\author{
"Quality is never an accident. It is always the result of an intelligent effort" - John Ruskin
}

It is our pleasure to publish the inaugural issue of the Journal of Global Hospitality and Tourism (JGHT). This new journal aims to provide an intellectual platform and ideas for international scholars, by promoting studies related to global hospitality and tourism. Editorial policy of JGHT focuses on publishing original research articles, review papers and communications that identify, explain, analyze, and review real-world business phenomena/issues.

Our vision is to make JGHT as one of the most innovative, proactive, and creative journals in our field and to establish itself as one of the leading academic journals in hospitality and tourism. To accomplish this vision, we have appointed international established scholars as well as many upcoming talented researchers to JGHT's editorial advisory board (EVB) and editorial review board (ERB). We are also proud to announce that we have a very good representation of individuals (in terms of geographical locations, gender, and academic position) on our EAB and ERB. We are also proud to announce that JGHT is a true open access journal which means that it is free to submit, publish, and/or access the content in the journal. It is made possible with the generous support from M3 Center for Innovation in Hospitality and Tourism and the University of South Florida Library.

While JGHT is an academic journal and focuses on research work conducted by academics working in higher education institutes; contributions to JGHT are particularly welcome from practitioners and professionals working in private, public, and non-profit organizations globally. JGHT welcomes theoretical, empirical, and applied manuscripts related to various sectors within the global hospitality and tourism industry to be considered for publication. Manuscripts can be based on theoretical arguments, empirical findings, case studies and/or methodological developments. Qualitative, quantitative, and mixed-methodology submissions are all welcome.

The first issue of JGHT includes five interesting and solid research articles and two viewpoints. The first article by Yuehan Cao, Jiyeon Jeon, Liang (Rebecca) Tang, and Xi Wang replicates an earlier study that analyzed hospitality and tourism research contributions in the first decade of the new millennium (Park et al., 2011) using a time frame of 2010-2019. Their study reviewed six toptier hospitality and tourism journals, including the International Journal of Hospitality Management, Journal of Hospitality \& Tourism Research, Cornell Hospitality Quarterly, Tourism Management, Journal of Travel Research, and Annals of Tourism Research. The papers were classified by research themes in the hospitality and tourism categories, respectively. The results offered the rankings by publication productivity pertaining to individual authors, universities, and countries/regions across the world. The findings give insights into future directions and identify research needs for academicians and industry practitioners in the hospitality and tourism field. 
The second article by Foad Irani and Hasan Kilic from Eastern Mediterranean University explores how to enhance hotels' environmental performance by adopting green human resource management practices. Their study developed and investigated a moderation model which examined the green process innovation as a moderator onto the relationship between green human resource management and environmental process through the lens of Ability-MotivationOpportunity theory. They collected data from 220 full-time employees of 3, 4, and 5-stars green hotels in Turkey. The findings demonstrated the importance of adopting green practices in advancing organizational performance, especially the environmental aspect. The novel findings of this study enrich the moderation effect of green process innovation in hospitality literature.

The third study is conducted by Jaewook Kim, Liang (Rebecca) Tang, Xi Wang, and Linan Zhang. This study aimed to examine the relationship among entrepreneurship capital, perceived feasibility, perceived desirability, and entrepreneurial intention in sharing lodging by using the entrepreneurial event model. Particularly, entrepreneurship capital was evaluated as a secondorder factor with four first-order sub-variables: financial, social, intellectual, and human capital. Data were collected from online surveys completed by 328 respondents. Second-order factor analysis and structural equation modeling were used in the analysis. Results confirmed that all four sub-variables contributed to inclusive capital. Inclusive capital positively influenced perceived feasibility and perceived desirability, which led to entrepreneurial intention. This study contributes to the evolving knowledge of sharing accommodations and enriches the research body of entrepreneurship via examining hosts of sharing lodging as innovative micro-entrepreneurs. It offers practical tools to help prospective hosts assess whether they are ready to operate a sharing lodging business.

The fourth study in this inaugural issue is conducted by Jessica Wiitala and Trishna Mistry. The purpose of this study was to analyze the relationships between hospitality organizations' crisis response during the COVID-19 pandemic with hospitality employees' attitudes and behaviors. Data was collected using a survey distributed on Amazon Mechanical Turk targeting hospitality industry employees. The findings reveal that crisis response is related to psychological well-being, job satisfaction, and organizational commitment among hospitality industry employees. This study broadens the scope of crisis management literature in the hospitality field. Furthermore, it establishes the significance of effective crisis response for hospitality industry employees' wellbeing and positive outcomes.

The last article presents a study conducted by Tammy Wee and Melissa L. S. Liow. This article aims to establish the motivation factors behind the accommodation choices made by millennials for stays at short-term rental properties and small hotels amidst the COVID-19 pandemic, a topic that remains under-represented in the hospitality and tourism literature. Using data from a survey of 145 millennials who stayed at an Airbnb property and a small hotel, a non-parametric test was utilized to compare six motivation factors that affect millennials' accommodation choices, guided by the push-pull motivational framework. The results showed that the millennials significantly considered price and reviews as their common pull motivations when making accommodation choices. Interestingly, motivation factors such as location, service quality, facilities and amenities, safety, and security do not appear to significantly influence the millennials' choices for either accommodation. This paper contributes to the limited pool of empirical research on short-term rental properties and addresses the challenges faced by the small hotel industry by focusing on millennials' accommodation choices. 
In addition to these five research papers, this issue of JGHT also two viewpoints. The first viewpoint is an academic one and is written by Prof. Mark S. Rosenbaum and Germán C. Ramírez. Their viewpoint suggests that foundational theories and concepts which characterize the services marketing discipline may no longer be valid due to the global pandemic. The authors discuss the impact of the Great Resignation on both consumers and organizations and posit that many consumers now accept lower levels of service offerings and performance. They further question whether organizations will ever return to pre-pandemic service levels. Further, the authors contend that the discipline's focus on employee-customer relationships has now shifted to customertechnology exchanges and that human interactions, in many service exchanges, are diminishing in importance. The authors put forward future research questions.

The second viewpoint is industry-based viewpoint and is contributed by Nancy Hutson from Full Stop Productions Inc., in Tampa, Florida USA. This viewpoint focuses on the event planning industry and takes a notion that while tourism and hospitality continue to show signs of rebounding, new, innovative strategies in event planning are needed more than ever.

We would like to congratulate all the authors on the successful completion of their research endeavors. We would also like to thank to all our reviewers for their insightful and constructive comments that assisted the authors to improve the quality of the papers. We hope that our readers will find all the papers published in this issue timely, relevant, and insightful. Finally, we want to thank our readers, authors, reviewers, EAB members, editorial team, and colleagues from M3 Center for Hospitality Technology and Innovation, University of South Florida, and Prof. Cihan Cobanoglu for their support and contribution to this first issue of JGHT as well as creating a platform and opportunity to launch JGHT.

\section{Editor-in-Chief}

Faizan Ali, Ph.D., Associate Professor, University of South Florida, United States

\section{Associate Editor}

Seden Dogan, Ph.D., Associate Professor, Ondokuz Mayis University, Turkey 